\title{
Molecular Diversity Analysis of Some Chilli (Capsicum spp.) Genotypes Using SSR Markers
}

\author{
Afsana Sharmin'1, Md. Ekramul Hoque ${ }^{1}$, Md. Masudul Haque², Fahima Khatun ${ }^{\text {1* }}$ \\ ${ }^{1}$ Department of Biotechnology, Sher-e-Bangla Agricultural University, Dhaka, Bangladesh \\ ${ }^{2}$ Regional Spices Research Centre, Bangladesh Agricultural Research Institute (BARI), Dhaka, Bangladesh \\ Email: afsana.hstu@gmail.com, hoque.biot@sau.edu.bd,masudul786@gmail.com, ^saufahima@gmail.com
}

How to cite this paper: Sharmin, A., Hoque, M.E., Haque, M.M. and Khatun, F. (2018) Molecular Diversity Analysis of Some Chilli (Capsicum spp.) Genotypes Using SSR Markers. American Journal of Plant Sciences, 9, 368-379.

https://doi.org/10.4236/ajps.2018.93029

Received: January 11, 2018

Accepted: February 10, 2018

Published: February 13, 2018

Copyright () 2018 by authors and Scientific Research Publishing Inc. This work is licensed under the Creative Commons Attribution-NonCommercial International License (CC BY-NC 4.0). http://creativecommons.org/licenses/by-nc/4.0/

\begin{abstract}
Chilli belongs to the genus Capsicum which possesses enormous wealth of genetic diversity. Extent of genetic diversity determines the success level of crop improvement programme. Simple sequence repeats (SSRs) are the most widely used marker system for molecular diversity analysis especially in cultivated species. The aim of our present study was to assess the molecular genetic diversity of 20 local chilli genotypes of Bangladesh using SSR markers. Genomic DNA was extracted from young leaves and PCR reactions were performed. Eleven SSR primers were used in PCR amplification. Total 10 alleles were detected for the five polymorphic SSR loci, with a mean of 2.00 alleles per primer. Gene diversity ranged from 0.333 to 1.00 with an average of 0.567 . Polymorphic Information Content (PIC) values of the SSR primers ranged from 0.255 to 0.500 with an average value of 0.371 . The similarity index matrix ranged from 0.00 to 1.000. It was highest in several germplasms viz. Pop-2 vs Pop-18; Pop-3 vs Pop-5 vs Pop-19 vs Pop-20 and the lowest in the germplasm Pop-8 vs Pop-18. Dendrogram based on Nei's genetic distance using Unweighted Pair Group Method of Arithmetic Means (UPGMA) indicated the segregation of 20 chilli genotypes into two main clusters. The SSR markers showed genetic variability in the studied pepper genotypes and they are powerful tools for estimating molecular diversity of chilli. The findings of the present study have potential applications in future breeding programme for the genetic improvement of chilli.
\end{abstract}

\section{Keywords}

Capsicum, Molecular Diversity, Genotypes, SSR Markers, Polymorphism

\section{Introduction}

Chilli (Capsicum spp.) originated from tropical and humid zone of Central and 
Southern America and belongs to the Solanaceae family having chromosome number $2 \mathrm{n}=2 \mathrm{x}=24$. Among the domesticated Capsicum species, pungent and non-pungent forms of Capsicum annuum L. (pepper) are most popular and have a worldwide commercial distribution [1]. Chilli is one of the most important horticultural and spice crop in Bangladesh. It is cultivated in all parts of the country throughout the year and used as green and dry stages for their pungency and colour [2].

Chilli has numerous chemicals including steam-volatile oil, fatty oils, carotenoids, vitamins, protein, fibre and mineral elements [1] and is used for different purposes because of their nutritional value, flavour, aroma, texture, pungency and colour. It also has antifungal property against fungal species belonging to Aspergillus and Fusarium [3]. It is source of Vitamin, A, B, C and E with minerals like molybdenum, manganese, folate, potassium, thiamin, and copper. Capsaicin has significant physiological action which is used in many pharmaceutical preparations and ointments for cold, sore throat, chest congestion etc. It is also used in cosmetics like prickly heat powders and skin ointments.

The chilli landraces of different district in Bangladesh are heterogeneous and a wide variability in respect of fruit morphology, pungency, bearing habit and crop duration is found throughout country. Bangladeshi chilli varieties have been developed traditionally by selection, hybridization and back crossing with locally adapted cultivars. An important source for the introduction of new traits is the existence of a genetically diverse pool of chilli germplasm available in the country but they are mostly lying unexplored. There is a strong need to collect this germplasm and their proper characterization and classification [4]. Subjective classification based on morphological data has been reported to create confusion and difficulty in classifying the genus capsicum [5]. In addition, the level of polymorphism for morphological characteristics in genotypes is sometimes so limited and inadequate to allow variety/genotype discrimination [6].

Molecular markers are important tool for genotype identification and studying the organization and evaluation of plant genome [7]. With the advent of molecular biology technique, large number of highly useful DNA markers has been developed for the identification of genetic polymorphism. Molecular markers define differences in nucleotide sequences, which are unaffected by growth stage, season, location, and agronomic practice [8]. Different molecular markers such as restriction fragment length polymorphisms (RFLPs), random amplified polymorphic DNAs (RAPDs), amplified fragment length polymorphisms (AFLPs), and simple sequence repeats (SSRs) have been developed for pepper [9] [10]. SSR markers represent highly polymorphic, reproducible, co-dominant, and multi allelic types of variation [11]. They are used in genome mapping, gene tagging, and estimation of genetic diversity, variety identification, and marker-assisted selection [12].

The main objective of this study is to capture the potential genetic diversity among chilli genotypes grown in Bangladesh and selection of suitable genotypes 
for future chilli hybridization programme. Hence, the present study was carried out for following objectives.

1) Molecular diversity analysis of different chilli genotypes.

2) Polymorphism study among chilli germplasm.

3) Dendrogram establishment in some local chilli genotypes.

\section{Materials and Methods}

\subsection{Experimental Site and Time Duration}

The experiment was conducted in Biotechnology Laboratory, Department of Biotechnology, Sher-e-Bangla Agricultural University (SAU), Dhaka-1207 and Regional Spices Research Centre, Bangladesh Agricultural Research Institute (BARI), Joydebpur, Gazipur-1701, Bangladesh.

\subsection{Plant Materials}

Twenty different chilli genotypes were used as plant materials for the study and were collected from different places of Bangladesh (Table 1). The genotypes were grown in poly bags placed in a shady place under the regular agronomic practices.

Table 1. List of chilli germplasm with their origin and characteristics.

\begin{tabular}{|c|c|c|c|}
\hline Sl. No. & Genotypes & Origin & Characteristics \\
\hline 1 & Pop-1 $\left(G_{1}\right)$ & Rangpur, Bangladesh & Large fruit size \\
\hline 2 & Pop-2 $\left(G_{2}\right)$ & Thakurgaon, Bangladesh & Small fruit size \\
\hline 3 & Pop-3 $\left(G_{3}\right)$ & Panchagarh, Bangladesh & Small fruit size \\
\hline 4 & Pop- $4\left(G_{4}\right)$ & Panchagarh, Bangladesh & Medium fruit size \\
\hline 5 & Pop-5 $\left(G_{5}\right)$ & Bogra, Bangladesh & Large fruit size \\
\hline 6 & Pop- $6\left(G_{6}\right)$ & Rangpur, Bangladesh & Medium fruit size \\
\hline 7 & Pop-7 $\left(\mathrm{G}_{7}\right)$ & Bogra, Bangladesh & Large fruit size \\
\hline 8 & Pop- $8\left(G_{8}\right)$ & Bogra, Bangladesh & Large fruit size \\
\hline 9 & Pop-9(G $\left.G_{9}\right)$ & Dinajpur, Bangladesh & Small fruit size \\
\hline 10 & Pop-11 $\left(\mathrm{G}_{10}\right)$ & Saidpur, Bangladesh & Medium fruit size \\
\hline 11 & Pop-12 $\left(\mathrm{G}_{11}\right)$ & Saidpur, Bangladesh & Medium fruit size \\
\hline 12 & Pop-13 $\left(\mathrm{G}_{12}\right)$ & Rangpur, Bangladesh & Large fruit size \\
\hline 13 & Pop-14 $\left(\mathrm{G}_{13}\right)$ & Bogra, Bangladesh & Small fruit size \\
\hline 14 & Pop-15 $\left(\mathrm{G}_{14}\right)$ & Thakurgaon, Bangladesh & Small fruit size \\
\hline 15 & Pop-16( $\left.\mathrm{G}_{15}\right)$ & Panchagarh, Bangladesh & Small fruit size \\
\hline 16 & Pop-17( $\left.\mathrm{G}_{16}\right)$ & Bogra, Bangladesh & Medium fruit size \\
\hline 17 & Pop-18 $\left(\mathrm{G}_{17}\right)$ & Dinajpur, Bangladesh & Small fruit size \\
\hline 18 & Pop-19 $\left(\mathrm{G}_{18}\right)$ & Saidpur, Bangladesh & Medium fruit size \\
\hline 19 & Pop-20 $\left(\mathrm{G}_{19}\right)$ & Bogra, Bangladesh & Small fruit size \\
\hline 20 & Pop- $21\left(\mathrm{G}_{20}\right)$ & Bogra, Bangladesh & Medium fruit size \\
\hline
\end{tabular}




\subsection{DNA Isolation}

Genomic DNA extractions from fresh young leaf at 3 - 4 leaf stage of seedling were done in SRC lab using CTAB (cetyl trimethyl ammonium bromide) buffer. CTAB extraction buffer was prepared by Doyle \& Doyle [13] method with some minor modification. Approximately $200 \mathrm{mg}$ of sterilized young leaves were used for DNA extraction. Extracted DNA was visualized in $1 \%$ agarose gel. Approximate 20 - 25 ng of DNA was used as template in PCR reaction.

\subsection{SSR Analysis}

Eleven SSR primers viz. GPMS-113, CAMS-117, CAMS-142, CAMS-153, GPMS161, GPMS-197, CAMS-327, CAMS-405, EPMS-418, CAMS-806 and CAMS-864 described previously were selected for PCR reaction on 20 local chilli germplasm for their ability to produce polymorphic band [14] [15] [16]. DNA amplification was performed in a thermal cycler (Esco Technologies Swift ${ }^{\mathrm{TM}}$ Mini Thermal cyclers, Singapore). The PCR reactions were performed in $10 \mu \mathrm{l}$ reaction mixture containing $5.0 \mu \mathrm{l} 2 \mathrm{X}$ Taq Master Mix, $1.50 \mu \mathrm{l}$ primers, $1.0 \mu \mathrm{l}$ sample DNA and $2.5 \mu \mathrm{l}$ de-ionized water (Biolab, UK). SSRs primers were amplified under the following PCR reaction conditions: Pre-denaturation with $95^{\circ} \mathrm{C}$ for $4 \mathrm{~min}$; denaturation with $95^{\circ} \mathrm{C}$ for $40 \mathrm{sec}$, annealing at $50^{\circ} \mathrm{C}-61^{\circ} \mathrm{C}$ (on the basis of $\mathrm{Tm}$ value of primer) for $33 \mathrm{sec}$, extension at $72^{\circ} \mathrm{C}$ for $40 \mathrm{sec}$, final extension at $72^{\circ} \mathrm{C}$ for 5 min continuing with 31 cycles and finally stored at $4^{\circ} \mathrm{C}$.

\subsection{Electrophoretic Separation of the Amplified Products}

PCR products for each sample were confirmed by running it in $2 \%$ agarose gel containing $1 \mu \mathrm{l}$ ethidium bromide in $1 \mathrm{X}$ TBE buffer at $90 \mathrm{~V}$ for 1 hour. Five microlitre $(5 \mu \mathrm{l})$ loading dye was added to the PCR product and spinned them well. Then it was loaded in the wells. The DNA ladder (50 \& 100 bp) (Promega thermal cyclers) was used in both left and right side of the gel. Under ultra-violet light on a trans-illuminator SSR bands were observed. The PCR product was saved by gel documentation system and photographed by a Gel Cam Polaroid camera.

\subsection{SSR Data Analysis}

The summary statistics including the number of alleles per locus, major allele frequency, gene diversity and Polymorphism Information Content (PIC) values were determined using POWER MARKER version 3.25 [17], a genetic marker data analysis software. The individual fragments were assigned as alleles of the appropriate microsatellite loci. The allele frequency data from POWER MARKER was used to export the data in binary format (presence of allele as "1" and absence of allele as "0") for analysis with NTSYS-PC (Numerical Taxonomy and Multiware Analysis System) Version 2.2 software [18]. Unweighted Pair Group Method of Arithmetic Means (UPGMA) dendrogram was constructed using a computer programme, POPGENE (Version 1.31) based on Nei's [19] genetic dis- 
tance. Diversity levels of loci were evaluated by polymorphic information content (PIC value) according to the formula [20].

$$
P I C=1-\sum_{j=i}^{n}\left(P_{i j}\right)^{2}
$$

where, $P_{i}$ is frequency of the jth pattern for marker $i$ and the summation extends over n patterns.

\section{Results}

Highly polymorphic and repeatable PCR based markers Simple Sequence Repeats (SSRs) were used here to assess the polymorphism, diversity and similarity identification within those local chilli germplasm. Results obtained from the study have been presented below under the following headings.

\subsection{Primer Selection and DNA Amplification through SSR Primer}

Eleven SSR primer pairs were screened on twenty chilli genotypes to evaluate their suitability for amplification of DNA. Among them five primer pairs CAMS-117, CAMS-153, GPMS-161, EPMS-418 and CAMS-806 showed reproducible and distinct polymorphic amplification. A total 10 alleles were detected for the five polymorphic SSR loci, with an average number of alleles/locus of 2.00 and a range between 1 to 3 alleles (Table 2). It was observed that one SSR primer GPMS-161 (Figure 1(c)) gave maximum number of allele (3) and allelic frequency ranging from 0.675 to 0.125 followed by CAMS-117, EPMS-418 and CAMS-806 SSR primer. In CAMS 153 SSR primers showed allelic frequency

Table 2. Primer sequence, number of allele, allele size and frequency of alleles and gene diversity index and PIC value at five SSR loci across 20 chilli genotypes.

\begin{tabular}{|c|c|c|c|c|c|c|}
\hline Primer code & Sequence of Primers $\left(5^{\prime}-3^{\prime}\right)$ & $\begin{array}{l}\text { Number } \\
\text { of Allele }\end{array}$ & $\begin{array}{l}\text { DNA Fragment } \\
\text { Size (bp) }\end{array}$ & $\begin{array}{c}\text { Allele } \\
\text { frequency }\end{array}$ & $\begin{array}{c}\text { Gene } \\
\text { Diversity }\end{array}$ & $\begin{array}{c}\text { PIC } \\
\text { Value }\end{array}$ \\
\hline CAMS-117 & $\begin{array}{l}\text { For: TTGTGGAGGAAACAAGCAAA } \\
\text { Rev: CCTCAGCCCAGGAGACATAA }\end{array}$ & 2 & $\begin{array}{l}220 \\
190\end{array}$ & $\begin{array}{l}0.850 \\
0.150\end{array}$ & 0.50 & 0.255 \\
\hline CAMS-153 & $\begin{array}{l}\text { For: TGCACAAATATGAATCCCAAGA } \\
\text { Rev: AGTCAGCAAACACATCTGACAA }\end{array}$ & 1 & 200 & 0.737 & 1.00 & 0.388 \\
\hline GPMS-161 & $\begin{array}{l}\text { For: GAAATCCAATAAACGAGTGAAG } \\
\text { Rev: CCTGTGTGAACAAGTTTTCAGG }\end{array}$ & 3 & $\begin{array}{l}240 \\
200 \\
140\end{array}$ & $\begin{array}{l}0.200 \\
0.675 \\
0.125\end{array}$ & 0.333 & 0.489 \\
\hline EPMS-418 & $\begin{array}{l}\text { For: ATCTTCTTCTCATTTCTCCСTTC } \\
\text { Rev: TGCTCAGCATTAACGACGTC }\end{array}$ & 2 & $\begin{array}{l}200 \\
180\end{array}$ & $\begin{array}{l}0.850 \\
0.150\end{array}$ & 0.500 & 0.225 \\
\hline CAMS-806 & $\begin{array}{l}\text { For: TGTCACAAGTGTCAAGGTAGGAG } \\
\text { Rev: CCCCAAAAATTTTCCCTCAT }\end{array}$ & 2 & $\begin{array}{l}210 \\
170\end{array}$ & $\begin{array}{l}0.500 \\
0.500\end{array}$ & 0.500 & 0.500 \\
\hline Total & - & 10 & & - & 2.833 & 1.857 \\
\hline Mean & - & 2.00 & & - & 0.567 & 0.371 \\
\hline
\end{tabular}


0.737 for only 1 allele (Table 2 ). The SSR primer CAMS-117 produced 2 DNA band ranges from $190 \mathrm{bp}$ to $220 \mathrm{bp}$ (Table 2) where $190 \mathrm{bp}$ was amplified in the genotypes of Pop-1, Pop-3, Pop-17 (Figure 1(a)) which is polymorphic in nature while primer CAMS- 153 produced 1 DNA fragment at $200 \mathrm{bp}$ (Table 2) where no polymorphic band was found (Figure 1(b)). In case of GPMS-161 primer, 3 DNA fragment was observed ranges from $140 \mathrm{bp}$ to $240 \mathrm{bp}$ (Table 2). The genotypes Pop-2, Pop-4 and Pop-10 were amplified at 190 bp DNA fragment (Figure 1(c)) which is polymorphic. Further, the SSR primer EPMS-418 and CAMS-806 produced 2 DNA amplification which was ranges from $180 \mathrm{bp}$ to $200 \mathrm{bp}$ and $170 \mathrm{bp}$ to $210 \mathrm{bp}$ (Table 2). The primer EPMS-418 gave $180 \mathrm{bp}$ fragments and it was polymorphic. It showed amplification in the genotypes Pop-1, Pop-3, Pop-18 (Figure 1(d)). The DNA band was amplified in the genotypes Pop-1, Pop-2 and Pop-3 showed polymorphism at 170 bp of DNA band in CAMS-806 (Figure 1(e)).

\subsection{Gene Diversity and Polymorphism Information Content (PIC)}

Gene diversity ranged from 0.333 to 1.00 . Primer CAMS-153 showed highest

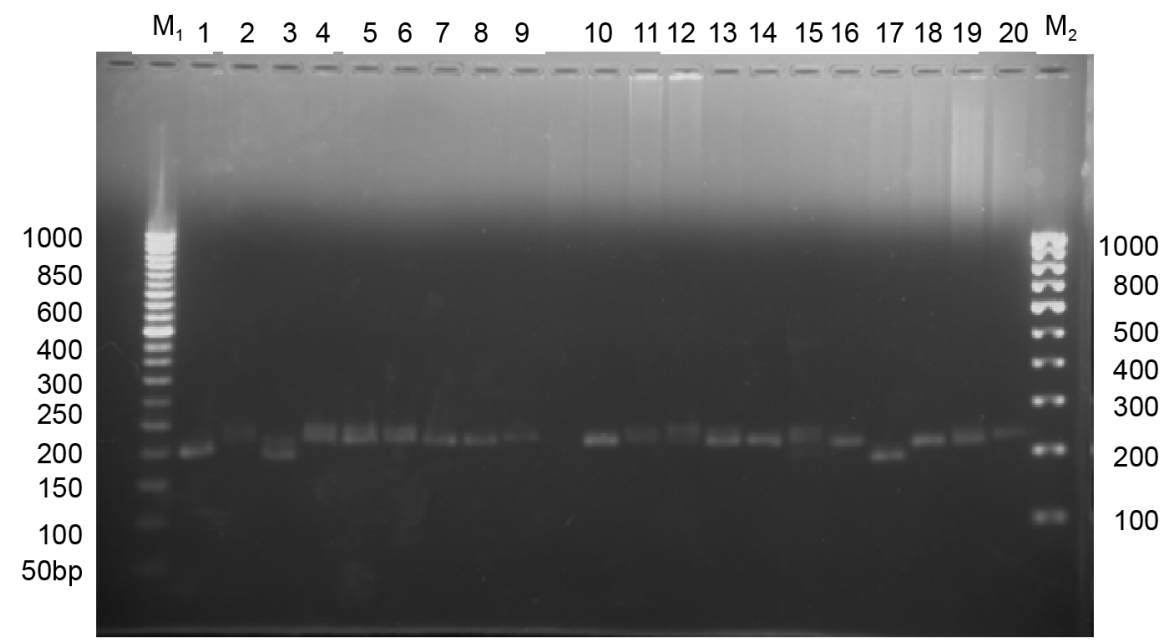

(a)
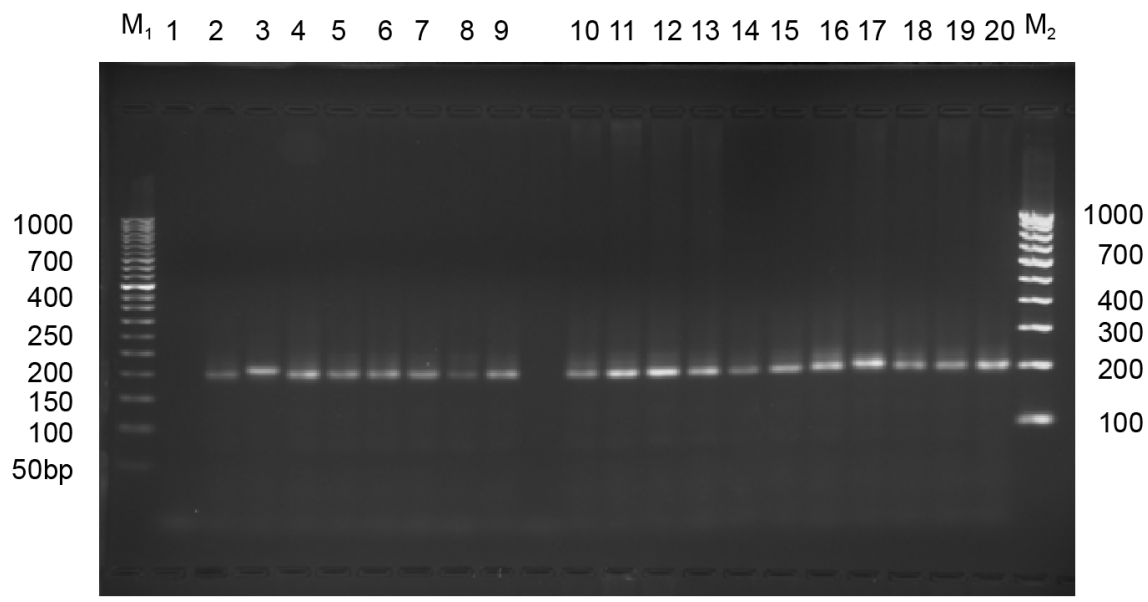

(b) 


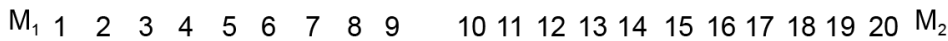

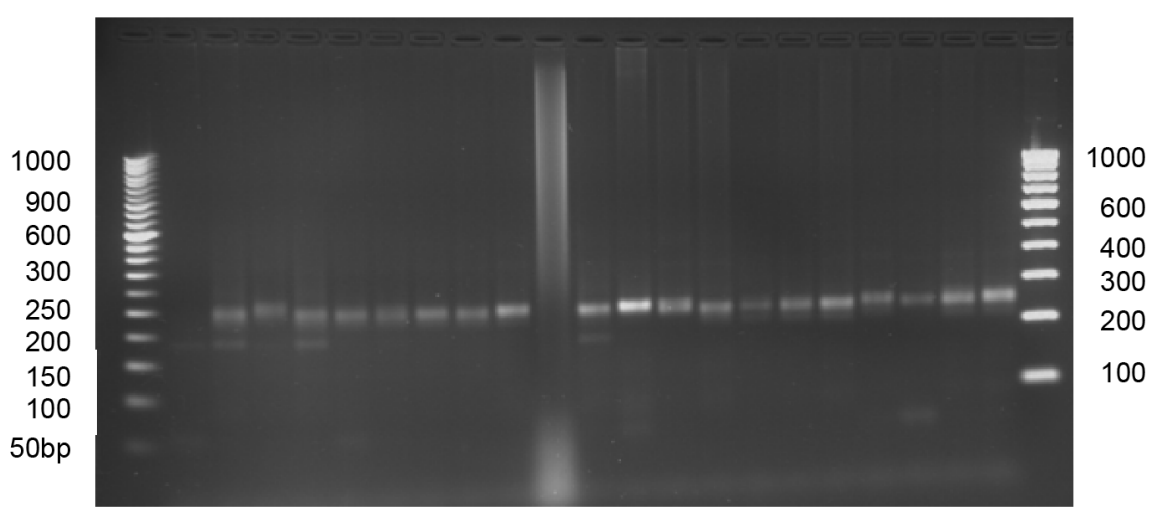

(c)

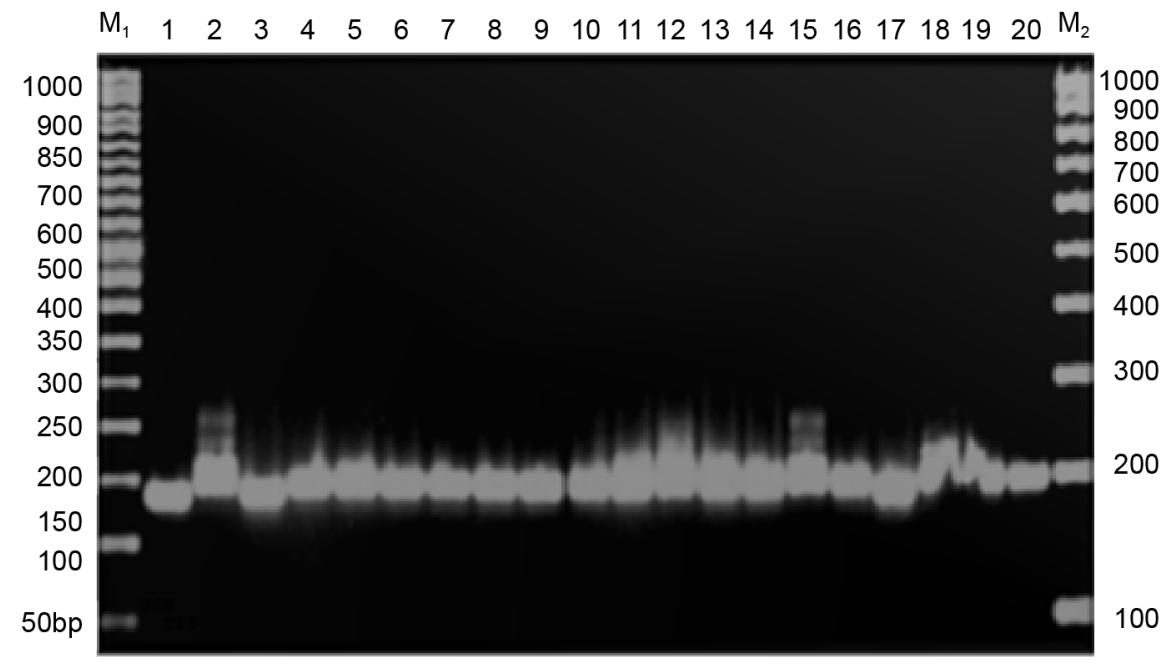

(d)
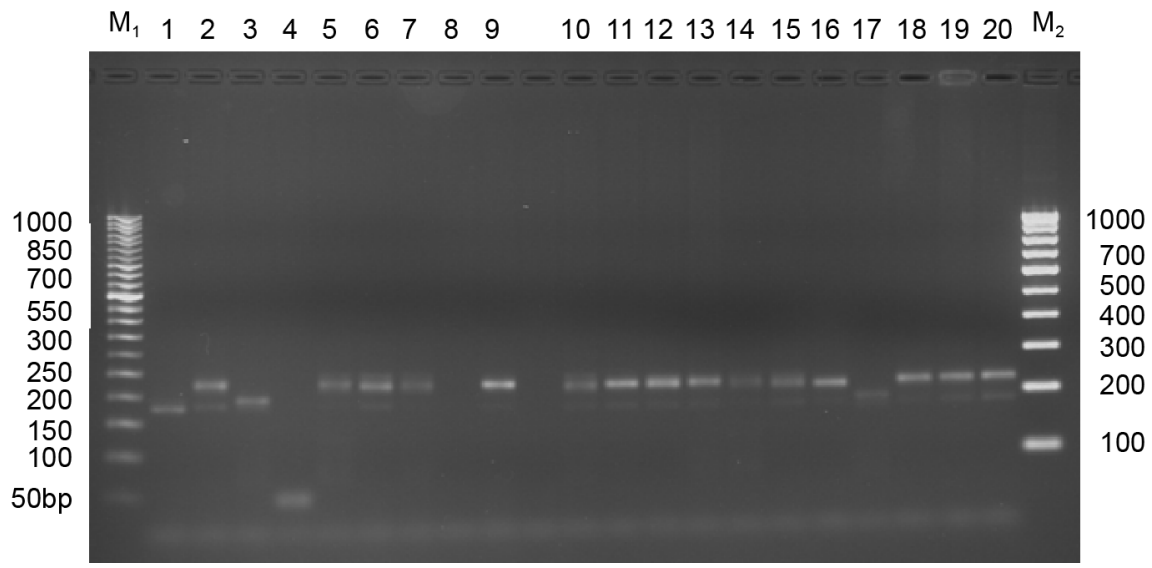

(e)

Figure 1. SSR profile of twenty chilli genotypes using primer (a) CAMS-117, (b) CAMS-153, (c) GPMS-161, (d) EPMS-418 \& (e) CAMS-806. $\mathrm{M}_{1}: 50$ bp DNA ladder and $\mathrm{M}_{2}$ : 100 bp DNA ladder. Lane 1 Pop-1; 2: Pop-2; 3: Pop-3; 4: Pop-4; 5: Pop-5; 6: Pop-6; 7: Pop-7; 8: Pop-8; 9: Pop-9; 10: Pop-11; 11: Pop-12; 12: Pop-13; 13: Pop-14; 14: Pop-15, 15: Pop-16; 16: Pop-17; 17: Pop-18; 18: Pop-19; 19: Pop-20 and 20: Pop-21. 
gene diversity (1.00) followed by CAMS-117, EPMS-418, CAMS-806 which was showed same gene diversity (0.500) (Table 2). Total genetic diversity obtained 2.833 with an average 0.567 . Polymorphic Information Content (PIC) value for the five markers ranged from 0.255 to 0.500 with a mean value of 0.371 . The highest PIC value (0.500) was obtained for CAMS-806 followed by GPMS-161 (0.489). The total PIC was 1.857 with an average 0.370 (Table 2). PIC value revealed that CAMS-806 was considered as the best marker for 20 chilli germplasm followed by GPMS-161 and CAMS-153. Primer CAMS-117 and EPMS-418 could be considered as the least powerful marker.

\subsection{Genetic Similarity Matrix}

The values of similarity coefficient were computed from combined data for the five primers, ranged from 0.00 to 1.000 . The highest genetic identity (1.00) was observed in Pop-2 vs Pop-18; Pop-3 vs Pop-5 vs Pop-19 vs Pop-20; Pop-4 vs Pop-18 vs Pop-19; Pop-13 vs Pop-14 vs Pop-15 vs Pop-16 vs Pop-18; whereas lowest genetic identity (0.00) was observed in Pop-8 vs Pop-18. The second largest genetic identity was 0.997 and they were present in Pop-4 vs Pop-20 and Pop-13 vs Pop-20 (Table 3). The difference between the highest and lowest

Table 3. Nei's (1972) genetic distance (below diagonal) values among 20 chilli genotypes.

\begin{tabular}{|c|c|c|c|c|c|c|c|c|c|c|c|c|c|c|c|c|c|c|c|c|}
\hline 势 & $\begin{array}{l}\overrightarrow{1} \\
\text { مे } \\
\text { مे }\end{array}$ & $\begin{array}{l}\text { İ } \\
\text { مे } \\
\text { مे }\end{array}$ & $\begin{array}{l}\text { r. } \\
\text { 仓ें } \\
\text { ¿े }\end{array}$ & $\begin{array}{l}+1 \\
\text { I. } \\
\text { oे } \\
\text { à }\end{array}$ & $\begin{array}{l}\text { in } \\
\text { oे } \\
\text { ò }\end{array}$ & $\begin{array}{l}0 \\
\stackrel{1}{ } \\
\text { oे } \\
\text { مे }\end{array}$ & $\begin{array}{l}\hat{1} \\
\text { 仓े } \\
\text { ¿े }\end{array}$ & $\begin{array}{l}\infty \\
\grave{1} \\
\text { ò } \\
\text { aे }\end{array}$ & $\begin{array}{l}\hat{a} \\
\hat{\partial} \\
\hat{a}\end{array}$ & $\begin{array}{l}\overline{1} \\
\text { aे } \\
\text { oे }\end{array}$ & $\begin{array}{l}\text { ㄱ. } \\
\stackrel{1}{\circ} \\
\stackrel{0}{2}\end{array}$ & 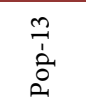 & 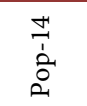 & $\begin{array}{l}\stackrel{n}{a} \\
\text { مे. } \\
\stackrel{2}{2}\end{array}$ & 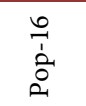 & $\begin{array}{l}\stackrel{\sim}{\dot{a}} \\
\stackrel{\circ}{\circ}\end{array}$ & $\begin{array}{l}\stackrel{\infty}{1} \\
\stackrel{1}{\circ} \\
\stackrel{2}{2}\end{array}$ & $\begin{array}{l}\text { ने } \\
\text { مे̀ } \\
\text { مे }\end{array}$ & 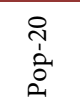 & 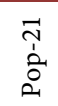 \\
\hline Pop-1 & $* * *$ & & & & & & & & & & & & & & & & & & & \\
\hline Pop-2 & 0.721 & $* * *$ & & & & & & & & & & & & & & & & & & \\
\hline Pop-3 & 0.615 & 0.747 & $* * *$ & & & & & & & & & & & & & & & & & \\
\hline Pop-4 & 0.811 & 0.027 & 0.838 & $* * *$ & & & & & & & & & & & & & & & & \\
\hline Pop-5 & 0.204 & 0.161 & 1.000 & 0.195 & $* * *$ & & & & & & & & & & & & & & & \\
\hline Pop-6 & 0.811 & 0.084 & 0.838 & 0.118 & 0.077 & $* * *$ & & & & & & & & & & & & & & \\
\hline Pop-7 & 0.911 & 0.309 & 0.821 & 0.352 & 0.123 & 0.218 & $* * *$ & & & & & & & & & & & & & \\
\hline Pop-8 & 0.504 & 0.353 & 0.838 & 0.325 & 0.195 & 0.251 & 0.352 & $* * *$ & & & & & & & & & & & & \\
\hline Pop-9 & 0.298 & 0.453 & 0.620 & 0.506 & 0.503 & 0.506 & 0.452 & 0.506 & $* * *$ & & & & & & & & & & & \\
\hline Pop-11 & 0.151 & 0.262 & 0.485 & 0.304 & 0.455 & 0.378 & 0.559 & 0.378 & 0.271 & $* * *$ & & & & & & & & & & \\
\hline Pop-12 & 0.250 & 0.5723 & 0.572 & 0.641 & 0.718 & 0.641 & 0.741 & 0.641 & 0.271 & 0.288 & $* * *$ & & & & & & & & & \\
\hline Pop-13 & 0.197 & 0.520 & 0.520 & 0.588 & 0.665 & 0.588 & 0.688 & 0.588 & 0.218 & 0.235 & 0.053 & $* * *$ & & & & & & & & \\
\hline Pop-14 & 0.358 & 0.430 & 0.692 & 0.483 & 0.560 & 0.483 & 0.503 & 0.665 & 0.670 & 0.535 & 0.248 & 0.328 & $* * *$ & & & & & & & \\
\hline Pop-15 & 0.869 & 0.430 & 0.915 & 0.483 & 0.560 & 0.483 & 0.670 & 0.665 & 0.503 & 0.718 & 0.248 & 0.328 & 0.100 & $* * *$ & & & & & & \\
\hline Pop-16 & 0.308 & 0.380 & 0.747 & 0.433 & 0.510 & 0.433 & 0.453 & 0.615 & 0.620 & 0.485 & 0.331 & 0.433 & 0.050 & 0.161 & $* * *$ & & & & & \\
\hline Pop-17 & 0.358 & 0.597 & 0.915 & 0.665 & 0.742 & 0.665 & 0.670 & 0.888 & 0.871 & 0.718 & 0.381 & 0.483 & 0.100 & 0.211 & 0.161 & $* * *$ & & & & \\
\hline Pop-18 & 0.911 & 1.000 & 0.715 & 1.000 & 0.983 & 0.817 & 0.841 & 0.000 & 0.705 & 0.098 & 0.964 & 1.000 & 1.000 & 1.000 & 1.000 & 0.871 & $* * *$ & & & \\
\hline Pop-19 & 0.358 & 0.915 & 1.000 & 1.000 & 0.742 & 0.888 & 0.670 & 0.888 & 0.458 & 0.074 & 0.718 & 0.888 & 0.337 & 0.480 & 0.430 & 0.211 & 0.871 & $* * *$ & & \\
\hline Pop-20 & 0.334 & 0.891 & 1.000 & 0.997 & 0.718 & 0.864 & 0.559 & 0.864 & 0.252 & 0.050 & 0.799 & 0.997 & 0.381 & 0.535 & 0.405 & 0.248 & 0.846 & 0.024 & $* * *$ & \\
\hline Pop-21 & 0.728 & 0.145 & 0.062 & 0.341 & 0.195 & 0.118 & 0.219 & 0.341 & 0.219 & 0.171 & 0.834 & 0.782 & 0.608 & 0.608 & 0.809 & 0.407 & 0.219 & 0.240 & 0.296 & $* * *$ \\
\hline
\end{tabular}


genetic identity indicates the presence of variability among 20 germplasm of chilli. Genetic distance among 20 chilli genotypes ranged from 0.024 to 0.911 . The highest genetic distance (0.911) was observed in Pop-1 vs Pop-7 vs Pop-18 genotype pairs, whereas lowest genetic distance (0.024) was estimated in Pop-19 vs Pop-20 (Table 3). The results revealed that the experimental materials showed highest genetic diversity. Genotypes pair with higher genetic distance is more dissimilar than a pair with a lower value. The lowest genetic distance indicating that they genetically much closer.

\subsection{Genetic Relationship (UPGMA Dendrogram)}

All the 20 chilli germplasm has been grouped into two main clusters. The first cluster further divided into two sub clusters. The sub clusters contains four genotypes (Pop-1, Pop-3, Pop-8 and Pop-18) (Figure 2). The second cluster also grouped into two sub clusters. There nine genotypes (Pop-2, Pop-4, Pop-5, Pop-6, Pop-7, Pop-9, Pop-11, Pop-12, Pop-13) in first sub cluster and seven genotypes (Pop-14, Pop-15, Pop-16, Pop-17, Pop-19, Pop-20, Pop-21) in second sub cluster of second cluster (Figure 2).

\section{Discussion}

SSR markers are considered more reliable because of their ability to produce highly consistent profiles [12]. Eleven SSR primers were screened on 20 chilli genotypes to evaluate their suitability for amplification of the DNA fragment.

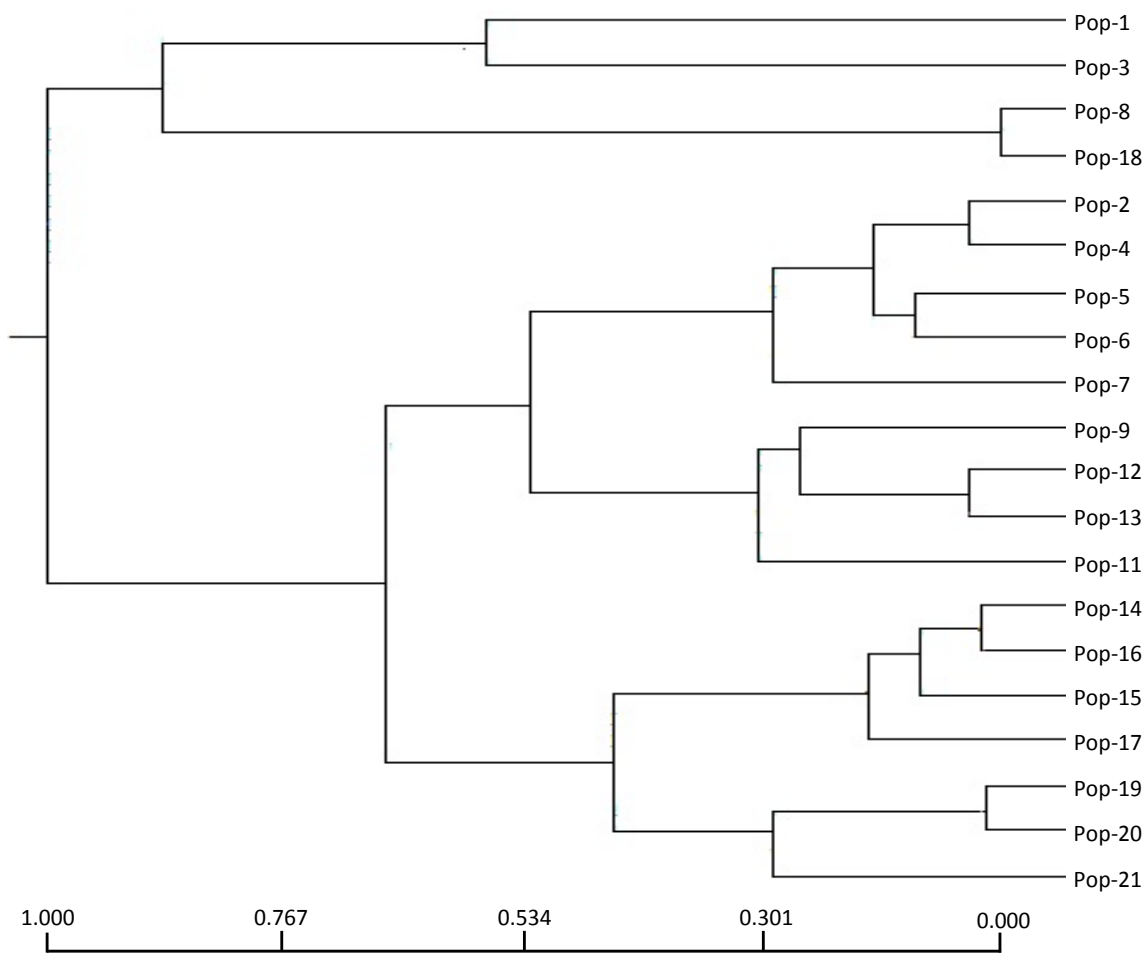

Figure 2. UPGMA dendrogram based on Nei's (1972) genetic distance, summarizing the data on differentiation between 20 chilli genotypes according to microsatellite analysis. 
The average number of alleles per locus provides complementary information of polymorphism and more adequate to co-dominant markers [21]. The average numbers of alleles (2.00) per SSR primer pairs were in agreement with earlier works reported in pepper with the mean value of 2.78 alleles/locus and maximum of four alleles were amplified by the primer AVRDC PP 32 [14]. Our observation were partially supported by Tilahun et al. [16] where they observed 3.22 average number of alleles per primer, range from 1 to 6 .

The PIC values provide an estimate of discriminating power of a marker by taking into account not only the number of alleles at a locus but also relative frequencies of these alleles. Lower PIC values might be result of closely related genotypes and vice versa. Senior et al. [22] opined that marker loci with an average number of alleles running at equal frequencies will have the highest PIC value. The PIC value obtained in present study varied from 0.255 to 0.500 with an average 0.371 . The highest PIC value (0.500) was obtained for CAMS-806. PIC value revealed that CAMS-806 was considered as the best marker for 20 chilli germplasm followed by GPMS-161 and CAMS-153. Primer CAMS-117 and EPMS-418 could be considered as the least powerful marker. Our results were partially consistent with Yumnam et al. [23] (0.52) and kwon et al. [24] (0.53). On the contrary, 65 polymorphic markers were validated among a wide collection of 21 Capsicum genotypes with allele number and polymorphic information content value per marker raging from 2 to 6 and 0.05 to 0.64 , respectively [25]. The varying levels of polymorphism in chilli pepper reported by various research group could be attributed to the differences in genetic structures of the populations screened and the molecular techniques used [14].

The gene diversity (GD) was 0.154 , indicating a considerable amount of polymorphism within this collection. The difference between the highest and lowest genetic identity indicates the presence of variability among 20 germplasm of chilli. Genetic distance among 20 chilli genotypes ranged from 0.024 to 0.911 . The highest genetic distance between them indicated that genetically they are diverged. Genotypes pair with higher genetic distance is more dissimilar than a pair with a lower value. This study indicated that the genotypes those showed the highest genetic variation can be used as parental source for breeding line to improve chilli varieties.

In this study, dendrogram revealed that the genotypes that derived of genetically similar type clustered together. Again, cluster analysis of the band patterns separated the varieties into three groups corresponding to varietal types. Morphological trait-based clustering showed some degree of similarity to dendrogram topologies based on the SSR index. This may be explained by that mostly SSR markers measures genetic variation mainly in non-coding sequences which possibly do not have a major impact on the morphology of genotype [24].

\section{Conclusion}

SSR markers showed genetic variability in the studied chilli genotypes and they are powerful tools for estimating genetic similarities and diversity. The genetic re- 
lationships presented among the genotypes are helpful for future breeding programs through selection of genetically diverse parents. The present work was the preliminary study to characterize and detect genetic variation of chilli varieties of Bangladesh and had some limitations in term of limited number of individuals and varieties as well as number of primers used. The results indicated that the present study might be used as a guideline for developing mapping population, marker assisted selection (MAS) and crop improvement of chilli varieties and consequently enables a genetic conservation plan in Bangladesh.

\section{Acknowledgements}

Authors are thankful to Sher-e-Bangla Agricultural University, Dhaka and NST fellowship program for providing financial assistance for research.

\section{References}

[1] Bosland, P.W. and Votava, E.J. (2000) Peppers: Vegetables and Spice Capsicums. Crop Production Science in Horticulture 12. CAB International Publishing, Wallingford, England, UK, 204.

[2] Basavaraj, N. (2008) Production on Cenario of Byadagi Chilli. Indian Journal of Arecanut Spices and Medicinal Plants, 9, 186-193.

[3] Lucca, A.J., Boue, S. and Palmgren, M.S. (2006) Fungicidal Properties of Two Saponins from Capsicum frutescens and the Relationship of Structure. Canadian Journal of Microbiology, 52, 336-342. https://doi.org/10.1139/w05-137

[4] Hossain, S.M., Habiba, U., Bhuyan, S.I., Haque, M.S., Begum, S.N. and Hossain, D.M. (2014) DNA Fingerprinting and Genetic Diversity Analysis of Chilli Germplasm Using Microsatellite Markers. Biotechnology, 13, 174-180. https://doi.org/10.3923/biotech.2014.174.180

[5] Costa, F.R., Pereira, T.N.S., Vitória, A.P., Campos, K.P., Rodrigues, R., Silva, D.H. and Pereira, M.G. (2006) Genetic Diversity among Capsicum Accessions Using RAPD Markers. Crop Breeding and Applied Biotechnology, 6, 18-23. https://doi.org/10.12702/1984-7033.v06n01a03

[6] Geleta, L.F., Labuschagne, M.T. and Viljoen, C.D. (2005) Genetic Variability in Pepper (Capsicum annuum L.) Estimated by Morphological Data and Amplified Length Polymorphism Markers. Biodiversity and Conservation, 14, 2361-2375. https://doi.org/10.1007/s10531-004-1669-9

[7] Joseph, A. (1993) A Taxocological Review Capsaicinoid (Oleorecin of Capsicums). Ruddick Hazardous Product Section, Environmental Health. Directorate Health and Welfare, Canada.

[8] Kwon, Y.S., Kim, K.M., Kim, D.H., Eun, M.Y. and Sohn, J.K. (2002) Marker-Assisted Introgression of Quantitative Trait Loci Associated with Plant Regeneration Ability in Anther Culture of Rice (Oryza sativa L.). Molecular Cell, 14, 24-28.

[9] Jang, I.O., Moon, J.H., Yoon, J.B., Yoo, J.H. and Yang, T.J. (2004) Application of RAPD and SCAR Markers for Purity Testing of F1 Hybrid Seed in Chili Pepper (Capsicum annuum). Molecular Cell, 18, 295-299.

[10] Lee, J.M., Nahm, S.H., Kim, Y.M. and Kim, B.D. (2004) Characterization and Molecular Genetic Mapping of Microsatellite Loci in Pepper. Theoretical and Applied Genetics, 108, 619-627. https://doi.org/10.1007/s00122-003-1467-x

[11] Becher, S.A., Steinmetz, K., Weising, K., Boury, S., Peltier, D., et al. (2000) Microsa- 
tellites for Cultivar Identification in Pelargonium. Theoretical and Applied Genetics, 101, 643-651. https://doi.org/10.1007/s001220051526

[12] McCouch, S.R., Chen, X.L., Panaud, O., Temnykh, S. and Xu, Y.B. (1997) Microsatellite Marker Development, Mapping and Application in Rice Genetics and Breeding. Plant Molecular Biology, 35, 89-99. https://doi.org/10.1023/A:1005711431474

[13] Doyle, J.J. and Doyle, J.L. (1990) Isolation of Plant DNA from Fresh Tissue. Focus, 12, 13-15.

[14] Dhaliwal, M.S., Yadav, A. and Jindal, S.K. (2014) Molecular Characterization and Diversity Analysis in Chilli Pepper Using Simple Sequence Repeats (SSR) Markers. The African Journal of Biotechnology, 13, 3137-3143. https://doi.org/10.5897/AJB2014.13695

[15] Rai, V.P., Kumar, R., Kumar, S., Rai, A., Kumar, S., Singh, M., Singh, S.P., Rai, A.B. and Paliwal, R. (2013) Genetic Diversity in Capsicum Germplasm Based on Microsatellite and Random Amplified Microsatellite Polymorphism Markers. Physiology and Molecular Biology of Plants, 19, 575-586. https://doi.org/10.1007/s12298-013-0185-3

[16] Tilahun, S., Paramaguru, P. and Bapu, J.R.K. (2013) Genetic Diversity in Certain Genotypes of Chilli and Paprika as Revealed by RAPD and SSR Analysis. Asian Journal of Agricultural Sciences, 5, 25-31.

[17] Liu, K. and Muse, S.V. (2005) Power Marker: An Integrated Analysis Environment for Genetic Marker Analysis. Bioinformatics, 21, 2128-2129.

https://doi.org/10.1093/bioinformatics/bti282

[18] Rohlf, F.J. (2006) NTSYS-pc. Numerical Taxonomy and Multivariance Analysis System, Version 2.02. Setauket, New York.

[19] Nei, M. (1972) Genetic Distance between Populations. The American Naturalist, 106, 283-292. https://doi.org/10.1086/282771

[20] Nei, M. (1973) Analysis of Gene Diversity in Subdivided Populations. Proceedings of the National Academy of Sciences of the United States of America, 70, 3321-3323.

[21] IPGRI (1999) Isolated from a Size-Fractionated Genomic Library of Brassica napus L. (Rapeseed). Theoretical and Applied Genetics, 91, 206-211.

[22] Senior, M.L., Murphy, J.P., Good, M.M. and Stuber, C.W. (1998) Utility of SSRs for Determining Genetic Similarities and Relationships in Maize Using an Agarose Gel System. Crop Science, 38, 1088-1098. https://doi.org/10.2135/cropsci1998.0011183X003800040034x

[23] Yumnam, J.S., Tyagi, W., Pandey, A., Meetei, N.T. and Rai, M. (2012) Evaluation of Genetic Diversity of Chilli Landraces from North Eastern India Based on Morphology, SSR Markers and the Pun1 Locus. Plant Molecular Biology Reporter, 30, 1470-1479. https://doi.org/10.1007/s11105-012-0466-y

[24] Kwon, Y.S., Lee, J.M., Gi-Bum,Y.I., Seung-In, Y.I., Kyung-Min, K.I.M., Eun-Hee, S., Kyung-Min, B., Eun-Kyung, P., In-Ho, S. and Kim, B.D. (2005) Use of SSR Markers to Complement Tests of Distinctiveness, Uniformity and Stability (DUS) of Pepper (Capsicum annum L.) Varieties. Molecular Cell, 19, 428-435.

[25] Cheng, J., Zhao, Z., Li, B., Qin, C., Wu, Z., Trejo-Saavedra, D.L., Luo, X., Cui, J., Rivera-Bustamante, R.F., Li, S. and Hu, K. (2016) A Comprehensive Characterization of Simple Sequence Repeats in Pepper Genomes Provides Valuable Resources for Marker Development in Capsicum. Scientific Reports, 6, Article ID: 18919. https://doi.org/10.1038/srep18919 